\title{
BMJ Open Multidimensional impact of severe mental illness on family members: systematic review
}

\author{
Wubalem Fekadu (D) ,1,2 Awoke Mihiretu, ${ }^{3}$ Tom K J Craig, ${ }^{4}$ Abebaw Fekadu ${ }^{3,5}$
}

\begin{abstract}
To cite: Fekadu W, Mihiretu A, Craig TKJ, et al. Multidimensional impact of severe mental illness on family members: systematic review. BMJ Open 2019:9:e032391. doi:10.1136/ bmjopen-2019-032391

- Prepublication history and additional material for this paper are available online. To view these files, please visit the journal online (http://dx.doi. org/10.1136/bmjopen-2019032391).
\end{abstract}

Received 17 June 2019 Revised 06 December 2019 Accepted 11 December 2019

Check for updates

(C) Author(s) (or their employer(s)) 2019. Re-use permitted under CC BY-NC. No commercial re-use. See rights and permissions. Published by BMJ.

${ }^{1}$ Department of Psychiatry, Addis Ababa University, Addis Ababa, Ethiopia

${ }^{2}$ Department of Psychiatry, Bahir Dar University, Bahir Dar, Ethiopia

${ }^{3}$ Department of Psychiatry, College of Health Sciences, Addis Ababa University, Addis Ababa, Ethiopia

${ }^{4}$ Department of Health Services and Population Research, King's College London, London, UK ${ }^{5}$ Center for Innovative Drug Development Therapeutic Studies for Africa (CDT-Africa), College of Health Sciences, Addis Ababa University, Addis Ababa, Ethiopia

Correspondence to Mr Wubalem Fekadu; wubfek@gmail.com

\section{ABSTRACT}

Objective The impact of severe mental illnesses (SMls) is not limited to the person with the illness but extends to their family members and the community where the patient comes from. In this review, we systematically analyse the available evidence of impacts of SMI on family members, including parents, grandparents, siblings, spouses and children.

Data sources PubMed, PsycINFO, Embase and Global Index Medicus were searched from the inception of each database up to 9 November 2019. We also did manual searches of grey literature.

Eligibility criteria We included studies that assessed the impacts of SMI on any family member. We excluded studies in admitted clinics and acute wards to rule out the acute effect of hospitalisation.

Data extraction Two reviewers extracted data independently using the Cochrane handbook guideline for systematic reviews and agreed on the final inclusion of identified studies.

Risk of bias The quality of the included studies was assessed using effective public health practice project quality assessment tool for quantitative studies. The review protocol was registered in the PROSPERO database.

Results We screened a total of 12107 duplicate free articles and included 39 articles in the review. The multidimensional impact of SMI included physical health problems (sleeplessness, headache and extreme tiredness.), psychological difficulties (depression and other psychological problems) and socioeconomic drift (less likely to marry and higher divorce rate and greater food insecurity). Impacts on children included higher mortality, poor school performance and nutritional problems. However, the quality of one in five studies was considered weak.

Conclusions Our review indicated a high level of multidimensional impact across multiple generations. The serious nature of the impact calls for interventions to address the multidimensional and multigenerational impact of SMI, particularly in low/middle-income countries. Given the relatively high number of studies rated methodologically weak, more robust studies are indicated. PROSPERO registration number CRD42018064123.

\section{INTRODUCTION}

Severe mental illnesses (SMIs), mainly schizophrenia, bipolar disorder and major
Strength and limitations of this study

Comprehensive search strategy.

- Screening, extraction and rating of articles carried out by two reviewers.

- Assessment of multidimensional impact across multiple generations.

- Meta-analysis was not possible because of the heterogeneity of studies.

depression, are conditions that tend to be chronic and relapsing in nature and may lead to serious impairment in one or more areas of functioning. ${ }^{1}$ SMIs decrease productivity and are associated with high rates of physical illness comorbidity and excess mortality. ${ }^{2-6}$ The negative impacts of SMI are not limited to the person with the illness but extend to the family members and the community where the person comes from. These impacts may particularly pronounce in low/ middle-income countries (LMICs), where the treatment gap for mental disorders is very high. In LMICs, family members or relatives take almost all the responsibility of caring for the patient and the impact transcends generations. $^{7-10}$

Caring for a person with mental illness takes a substantial toll on social relationships, employment and income and psychological well-being. ${ }^{11}$ Most families fear for their future health in addition to the stress of caring for their ill family member. ${ }^{910}$ Families of people with SMI have worse physical health and seek more medical care than those families without SMI. ${ }^{12} 13$

Children of people with SMI have higher risk of developing physical and mental illness for a variety of reasons, including stigma, financial difficulties, the burden of caring for ill parents and genetic vulnerability. The impact on children is long term and affects their adult health and relationships. ${ }^{14-18}$

There is no agreement in the literature about the level of burden in relation to 
amount of time spent on caregiving. Some studies relate the burden level with time spent for caregiving ${ }^{19-21}$ while others evaluate the burden at the household level. ${ }^{22} 23$ Some studies also measure the impact of the illness on extended families such as grandparents and family members living in separate households with no direct contact with the patient. ${ }^{24} 25$

Although there are small-scale studies and some literature reviews on aspects of the impact of SMI on family members ${ }^{26-28}$ there are no reviews looking at the multidimensional impact of different types of SMI across generations. This paper aims to systematically review the available evidence on the impacts (health, socioeconomic and schooling) of schizophrenia, bipolar disorder and major depression on family members.

\section{METHODS}

This systematic review was conducted in accordance with the Preferred Reporting Items for Systematic Reviews and Meta-Analyses guidelines. ${ }^{29}$ We have registered the protocol on the PROSPERO international register of systematic reviews online.

\section{Search strategy}

Four databases were searched: PubMed, Embase, PsycINFO and Global Index Medicus. The databases were searched from the inception of each database up to 9 November 2019 with no language restriction. We did a forward and backward search on included studies and hand searching for grey literature from Google Scholar and university repositories.

The search terms consisted of key Medical Subject Heading (MeSH) and Emtree terms, and controlled vocabularies for illness, list of family members affected by the illness and impact dimensions. The terms were combined with the Boolean term AND:

1. Terms for illness: 'Severe mental illness' OR schizophrenia OR psychosis OR bipolar OR 'major depressive disorder' OR 'major depression'

2. Terms for list of family member affected by the illness: Caregiver OR family OR parent* OR child OR offspring OR siblings OR spouse.

3. Terms for impact dimensions: Burden OR Impact health OR morbidity OR mortality OR disability OR Psychopathology OR poverty OR economy OR financial OR education OR school. A full search strategy and search terms for databases can be accessed in a supplementary file (online supplementary file 1 ).

\section{Eligibility criteria}

We have included peer-reviewed studies that met the following criteria:

\section{Participant}

Any family member(s) or informal caregiver(s) (biologically related or not) of people with clinically diagnosed SMI (schizophrenia, bipolar disorder and major depression).

\section{Duration of illness}

Duration of illness 1 year or longer. If the duration was not mentioned, we have excluded studies in acute inpatients and acute wards to rule out the acute effect of hospitalisation.

\section{Exposure}

SMI.

\section{Outcome}

Burden/impact (positive and negative) and its dimensions excluding family genetic studies.

Study design

All excluding qualitative studies, case report and case series.

Publication year

Not restricted.

\section{Data extraction}

Studies were first screened on title and abstracts by two reviewers (WF and AM) independently. The two reviewers extracted data independently using the Cochrane handbook guideline for systematic reviews. ${ }^{30}$ Discrepancies were resolved with discussion. The excluded articles and the reasons for exclusion were documented. Author, publication year, country, aim, study design, population, sample size, type of illness, duration, key outcomes (including measures) were extracted. The proportion of agreement between the two reviewers during the title and abstract screening was $91 \%$ and $96 \%$ in the full-text screening.

\section{Assessment of bias}

Two reviewers assess the risk of biases independently and reconciled with effective public health practice project (EPHPP) quality assessment tool for quantitative studies. ${ }^{31}$ The tool consists of eight criteria of which six were rated: selection bias, allocation bias, control of confounders, blinding of outcome assessors, data collection methods, and withdrawals and dropouts. Each section was rated as 'weak', 'moderate' or 'strong'. A global rating of each article was decided as weak, moderate and strong (online supplementary file 2 ).

\section{RESULTS}

\section{Study selection}

In total, 13102 articles were identified in the initial search. A total of 12107 articles were eligible for title and abstract screening after removing 1143 duplicates. Four hundred 


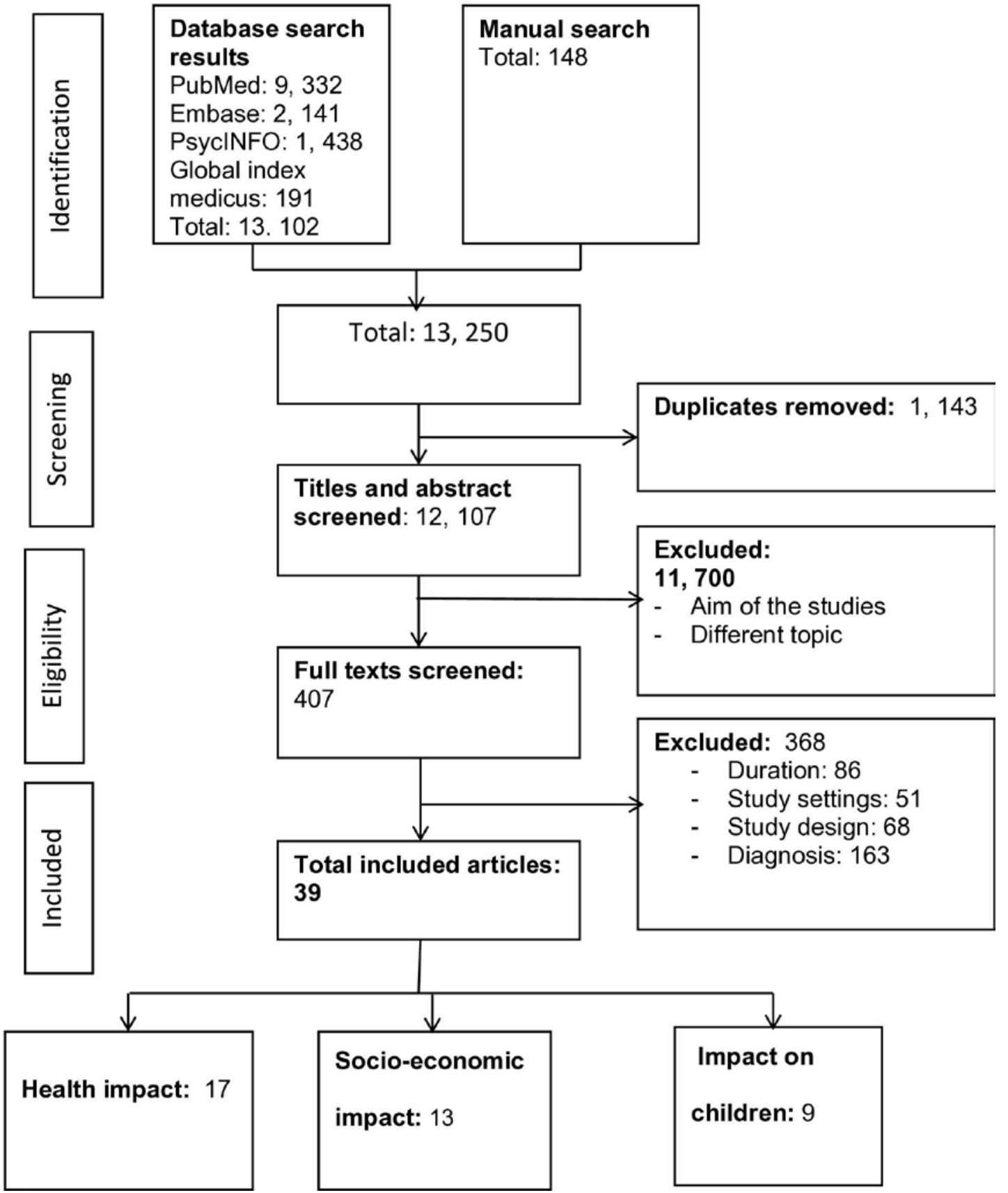

Figure 1 Preferred Reporting Items for Systematic Reviews and Meta-Analyses flow diagram of study selection process.

seven articles were eligible for whole paper review after removing 11700 articles at the title and abstract screening stage, mainly because the study did not concern SMI. Three hundred sixty-eight articles were not eligible for the final manuscript because of short illness duration, lack of clinical diagnosis, study setting (in acute wards and inpatients), focus of the studies and study design (figure 1). We found six articles written in languages other than English. All had abstracts in English, but none fulfilled the inclusion criteria and so were not included in the final extraction. A total of 39 articles included in the review.

\section{Study characteristics}

Thirty-nine studies were included in the final review, which were conducted in 20 different counties, mostly high-income countries ( $\mathrm{n}=30,76.9 \%)$. Most studies were conducted in Europe $(n=14)$ and USA $(n=9)$. The rest comes from Asia $(n=6)$, Africa $(n=6)$ and Latin America $(\mathrm{n}=4)$.

Sixteen $(41 \%)$ studies were longitudinal, and the remaining were cross-sectional (with and without a comparison group) and case control studies. The publication year ranged from 2001 to 2018, while the durations of illness ranged from 1 year to 30 years. Eighteen of the studies focused on family members of people with schizophrenia, eight were done on bipolar disorder, four on major depressive disorder (MDD) while the remaining nine on SMIs. The impact dimensions included health $(n=17)$, socioeconomic $(n=13)$ and impact on children: 
education, nutrition, mortality $(n=9)$. The sample size of the studies ranged from 51 up to 5504. Two birth cohorts involved large sample sizes: one with 684248 birth children and another study have 3654 cases and 1439215 controls (tables 1 and 2).

\section{Risk of bias within studies}

Nineteen studies were rated as strong, twelve moderate and the remaining eight were rated as weak in the global rating of the articles with EPHPP. Only six out of the thirty-nine studies were considered free from selection bias while the remaining studies had moderate to weak selection bias problems. Thirty-three studies failed to control for most of the confounders and nine out of thirty-nine were weak in controlling confounders. Twenty-seven studies were conducted with valid and reliable instruments.

\section{Impacts}

The main impact dimensions were related to health, economic and social domains, and impact on children's education and nutrition.

\section{Impact on health and quality of life}

Seventeen studies reported the health impact of having a family member with SMI; two studies reported overall health impact, three assessed physical health and the remaining reported on psychological impact.

Two studies report low mental and physical composite score measured with the Short-Form 36 compared with healthy controls. ${ }^{3233}$ Family members have poor perceived physical health $(65.5 \%)$, sleeplessness $(53.1 \%)$, headache $(44.2 \%)$ and extreme tiredness $(56.2 \%)$. These physical problems were significantly higher in family members of people with SMI than the family members who did not have SMI: sleep problems ( $42.7 \%$ vs $28.5 \%)$, pain $(39.7 \%$ vs $30.4 \%)$, headache ( $48 \%$ vs $42 \%$ ) and heartburn $(31.7 \%$ vs $22.9 \%) .{ }^{113435}$

The magnitude of psychological problems in family members was high ${ }^{36-39}$ including parents, siblings, children and grandchildren of people with SMI. One study reported higher depression score (Centre for Epidemiological Studies of Depression Scale) among parents of adult children with bipolar disorder compared with comparisons. ${ }^{33}$ Another study report higher psychological distress in family members of people with schizophrenia than the controls $(0.70$ vs 0.34$) .^{40}$

Two studies found $20 \%-50 \%$ of caregivers experience depressive symptoms. ${ }^{34}$ In one multicounty study, depressive symptoms were also reported by $29.4 \%$ of caregivers of people with schizophrenia compared with $19.4 \%$ in matched controls. ${ }^{35}$

Families with a depressed grandparent experience more anxiety and other psychiatric disorders compared with non-depressed grandparents $(24,25,33,43)$.

\section{Socioeconomic impact}

Difficulties in social relationships and family finances were also reported by several studies. The social impacts included higher divorce rate, fewer marriages, poor family cohesion and a strained family environment. Some studies report these impacts on a family member while others report across the entire household.

Family members with mental illness reported less chance of marriage (eg, $54.7 \%$ in children of parents with schizophrenia vs $66 \%$ in general population) and higher divorce rate (eg, $20 \%$ in parents of adult children with bipolar disorder vs $10.2 \%$ in controls) ${ }^{33} 39$ Family cohesion is lower and the environment in these families was also strained in these family members. ${ }^{23} 41$

Financial impact was higher than other impact dimensions in three studies. ${ }^{42-44}$ These economic impacts were due to costs related to care (cost for treatment, cost of informal care giving), productivity (inability to work and time for care giving) and cost of treatment side effects, suicide and stigma. For example, in one study, out-ofpocket medical expense per year was higher in caregivers of people with bipolar disorder (US\$93.93) than caregivers of other medical conditions (US\$64.8) and general population comparisons (US\$56.18). ${ }^{45}$ Family members ability to pursue regular activities was also affected. ${ }^{46}$

The economic impact might result in long-term economic drift and food insecurity. One study found $32.5 \%$ of households of people with SMI experience severe food insecurity compared with $15.9 \%$ among the general population. ${ }^{22}$

\section{Impact on children}

Four studies reported the level of psychopathology in children of parents with SMI. In one study the level of psychopathology differed by the specific type of illness. In this study $58.5 \%$ of the children of parents with a diagnosis of schizophrenia had lifetime axis I Diagnostic Statistical Manual IV (DSM-IV) psychiatric disorder compared with $36.7 \%$ of children of parents with bipolar disorder and $17.8 \%$ in children of healthy parents. ${ }^{47}$

One longitudinal study reported $38.7 \%, 35.6 \%$ and $15.2 \%$ lifetime psychiatric disorders in children of parents with schizophrenia spectrum and other psychotic disorders, children of parents with bipolar disorder and children of parents without any mental disorder, respectively. ${ }^{48}$

Psychopathology was compared by two matched studies. It was reported by $63 \%$ in offspring of parents with bipolar disorder and $33 \%$ in matched controls, while current axis I disorder was reported by $21.33 \%$ exposed offspring and $14 \%$ among controls. ${ }^{49}{ }^{50}$ These children also receive more counselling $(30.9 \%$ vs $13.5 \%)$, take medication ( $18.7 \%$ vs $5.3 \%)$ and experience more psychiatric hospitalisations. ${ }^{49}$

Children's level of functioning was also affected. ${ }^{48} 50$ These children had poorer school performance and they were more likely to be placed in special rooms at school and face malnutrition. ${ }^{49}{ }^{51-53}$ The impact of the parent's illness on children reported by one study to be long lasting. In this study, children of parents with MDD had higher 
Table 1 Impact of SMI on family members in LMICs

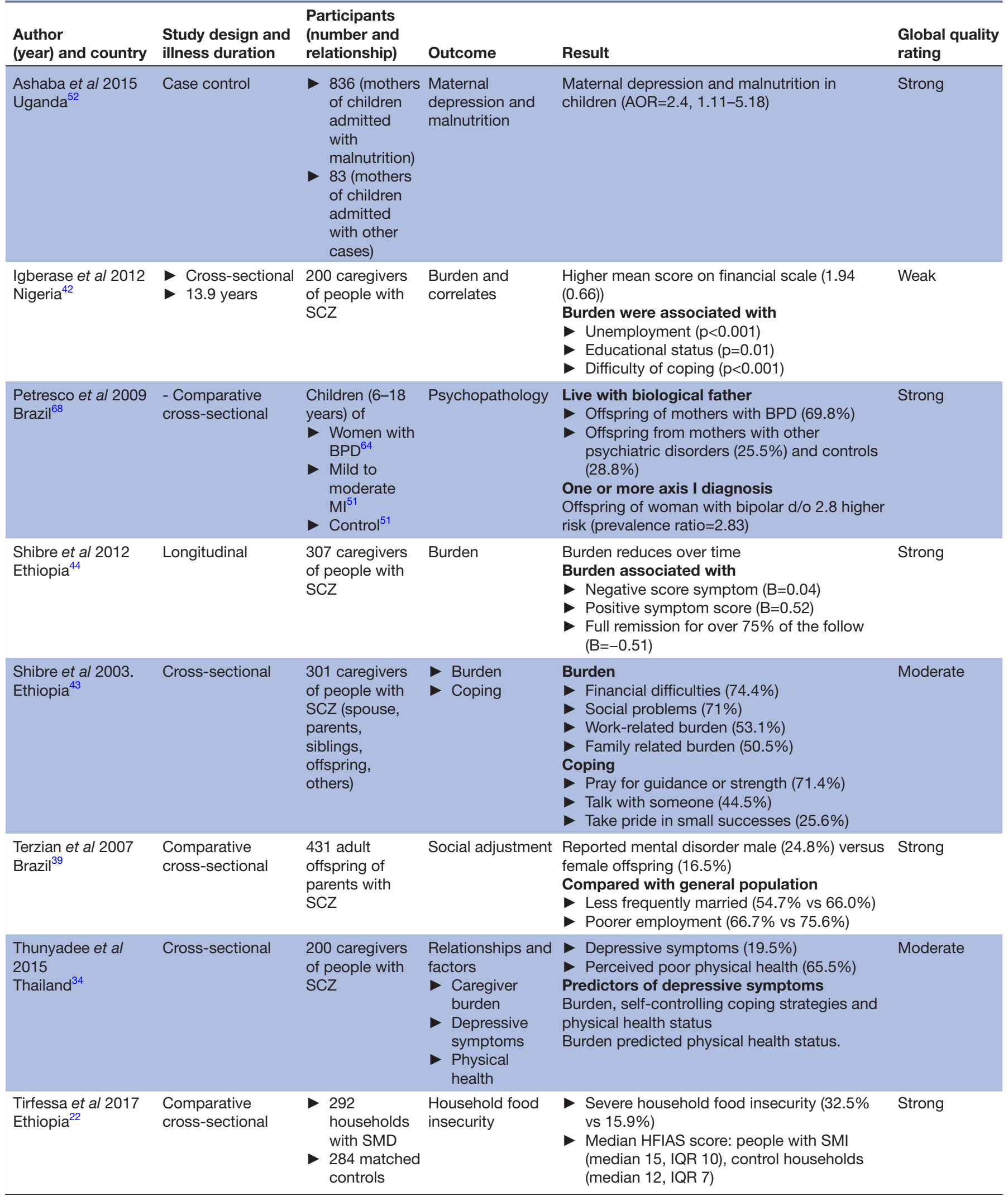

Continued 
Table 1 Continued

\begin{tabular}{|c|c|c|c|c|c|}
\hline $\begin{array}{l}\text { Author } \\
\text { (year) and country }\end{array}$ & $\begin{array}{l}\text { Study design and } \\
\text { illness duration }\end{array}$ & $\begin{array}{l}\text { Participants } \\
\text { (number and } \\
\text { relationship) }\end{array}$ & Outcome & Result & $\begin{array}{l}\text { Global quality } \\
\text { rating }\end{array}$ \\
\hline $\begin{array}{l}\text { Zergaw et al } 2008 \\
\text { Ethiopia }^{45}\end{array}$ & Longitudinal & $\begin{array}{l}139 \\
\text { caregivers of } \\
\text { people with } \\
\text { BPD } \\
36 \text { diabetes, } \\
\text { hypertension } \\
\text { and asthma } \\
401 \text { controls }\end{array}$ & $\begin{array}{l}\text { Economic } \\
\text { General } \\
\text { burden }\end{array}$ & $\begin{array}{l}\text { Burden inducing event occur in 8-10 months/ } \\
\text { year versus may not occur } \\
\text { Out-of-pocket medical expense/year } \\
\text { 93.93US } \$-\text { bipolar } \\
\text { 64.8US\$-DHA } \\
\text { 56.18US } \$-\text { control (not statistically } \\
\text { different) }\end{array}$ & Strong \\
\hline
\end{tabular}

AOR, adjusted OR; BPD, bipolar disorder; DHA, diabetes hypertension asthma; d/o, disorder; HFIAS, household food insecurity assessment schedule; LMIC, low/middle-income countries; MI, myocardial infarction; SCZ, schizophrenia; SMD, severe mental disorder; SMI, severe mental illness.

mortality $(5.5 \%$ vs $2.5 \%)$ with 8 years mean age difference after 30 years compared with healthy controls. ${ }^{24}$

\section{Predictors}

The level of impact of the illness depends on patientrelated factors, family member-related factors and factors related to health service delivery. The major patientrelated factors were type of illness, severity and profile of symptoms. The other factors such as age of onset, duration of illness, number of hospitalisations and current functioning also predict the level of impact. ${ }^{36} 40414454-56$ These factors are also seen in Ethiopia where the level of burden was associated with symptom severity, disability and remission..$^{22} 44$

Family member-related factors include relationship type, sex, economic and educational status, living in the same home and coping mechanisms. ${ }^{41} 42465758$ For example, in Chile, mothers developed higher burden than other family members ${ }^{54}$ and in Taiwan parents experience higher burden than children. ${ }^{58}$ The burden was also associated with unemployment, educational status and coping mechanisms of family members. ${ }^{42}$

The impact may also depend on the healthcare system and financial investment for mental healthcare as evidenced by a difference in burden between two cities of China (Hong Kong and Guangzhou) and in Germany and Britain. For example, the level of caregivers burden in Britain was higher than in Germany (Involvement Evaluation Questionnaire Score: 46.1 vs 43.2) which has been attributed to the relatively lower financial investment on mental health in Britain ${ }^{59}{ }^{60}$ (tables 1 and 2).

\section{DISCUSSION}

This is the first systematic review, which synthesises the global evidence on the impact of SMI on family members. Previous reviews have focused on primary caregivers, not the impact of the illness on other family members. ${ }^{26-28}$ These unrecognised impacts have effects on the person with the illness, the family and the community at large. The impact may be more pronounced in low-income countries because the family relationship is more extended, social security is not available and higher level of stigma and discrimination ${ }^{61-63}$

Earlier studies focus mainly on schizophrenia and bipolar disorder, ${ }^{26-28}$ while our review includes the impact of severe depression on family members. This review also attempts to assess long-term, diverse impacts across the three specific illnesses and across multiple generations. These are essential inputs to develop family inclusive interventions.

It is of note that about one in five studies $(8 / 39$ studies) were rated as weak in global rating. While this constitutes an important limitation of this systematic review, we have presented the data irrespective of the methodological problems and quality. All the included studies had fulfilled the required inclusion criteria. Moreover, six of the eight studies rated weak had at least one strong rating and that all the studies have at least three of the six quality assessment items of the EPHPP criteria rated as strong or moderate. Moreover, we consider presenting the results of all studies fulfilling the inclusion criteria along with the quality of the studies will assist the readers to understand the reports and plan for further studies.

The health impact was common across the three specific illnesses, both in high/low-income countries ${ }^{11} 343947$ and it is long-term and trans-generational. ${ }^{24} 253364$ Psychological distress and physical complaints in family members can be explained by stressful family environment and high demand for care by the people with the illness. ${ }^{23} 3448$ When this comes on top of other personal or economic difficulties, it has been suggested that the combination may result in psychological or physical ill health. ${ }^{65} 66$ However, it is not clear just how serious this can be. For example, the burden get so high as to lead to severe psychological problems such as suicidal behaviour or increased mortality. This has been suggested by Vitaliano et $a l^{67}$ who showed how caregiving for Alzheimer's might even end up in death of the caregiver, an endpoint which might also apply to caring for SMI. ${ }^{67}$ 
Table 2 mpact of SMI on family members in high-income countries

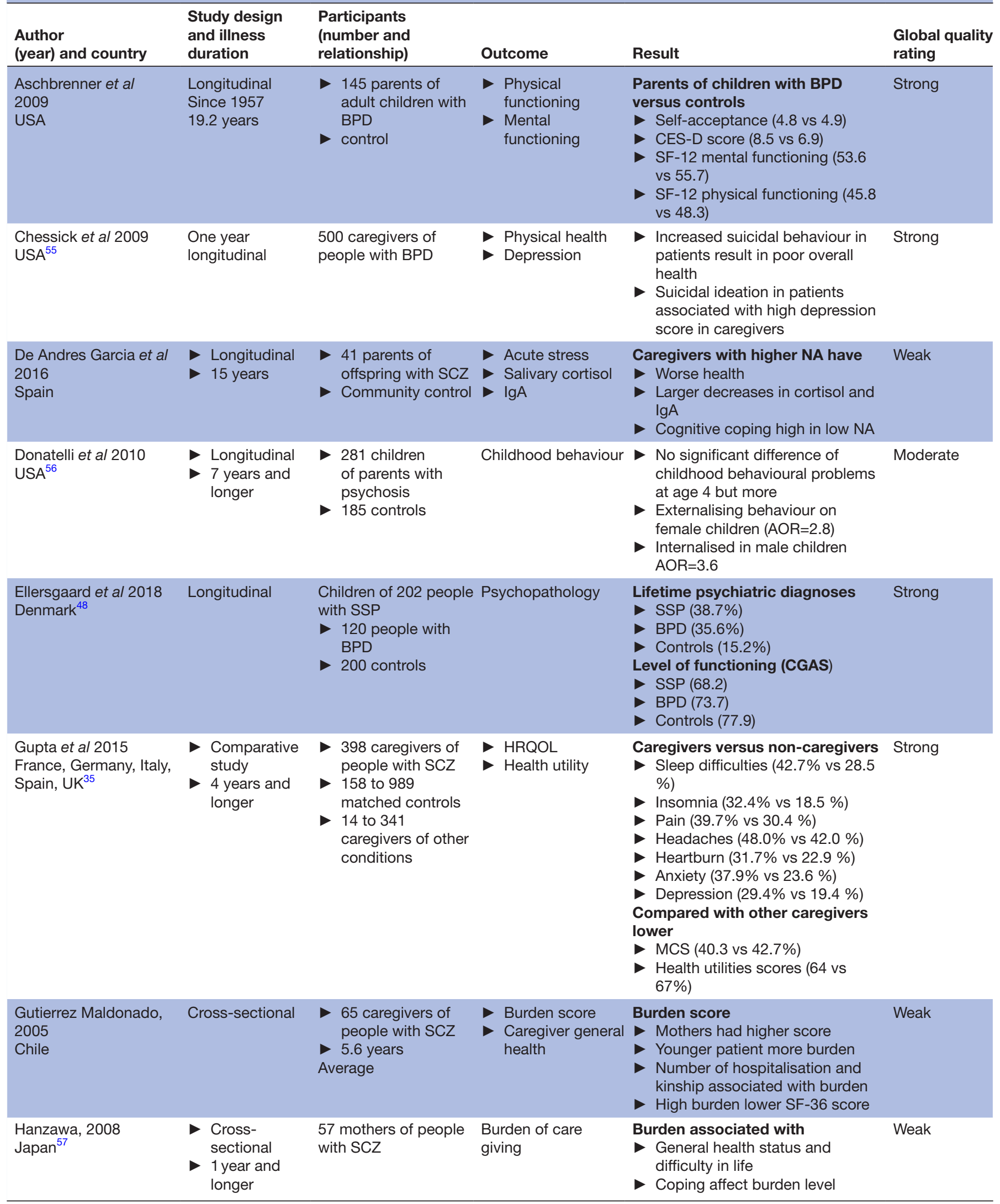

Continued 


\section{Table 2 Continued}

\begin{tabular}{|c|c|c|c|c|c|}
\hline $\begin{array}{l}\text { Author } \\
\text { (year) and country }\end{array}$ & $\begin{array}{l}\text { Study design } \\
\text { and illness } \\
\text { duration }\end{array}$ & $\begin{array}{l}\text { Participants } \\
\text { (number and } \\
\text { relationship) }\end{array}$ & Outcome & Result & $\begin{array}{l}\text { Global quality } \\
\text { rating }\end{array}$ \\
\hline $\begin{array}{l}\text { Henin et al } 2005 \\
\text { USA }^{49}\end{array}$ & $\begin{array}{l}\text { Comparative } \\
\text { cross-sectional }\end{array}$ & $\begin{array}{l}117 \text { offspring of } \\
\text { parents with BPD } \\
171 \text { age and } \\
\text { gender matched } \\
\text { offspring }\end{array}$ & $\begin{array}{l}\text { Hospitalisation } \\
\text { Placement in } \\
\text { special classes } \\
\text { Medication }\end{array}$ & 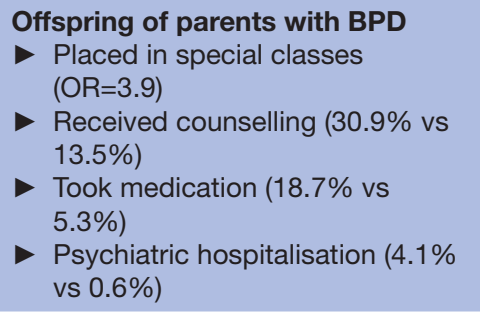 & Strong \\
\hline $\begin{array}{l}\text { Hsiao, Tsai, } 2014 \\
\text { Taiwan }\end{array}$ & $\begin{array}{l}\text { Cross- } \\
\text { sectional } \\
\text { Average } 12.67 \\
\text { years }\end{array}$ & $\begin{array}{l}243 \text { caregivers of } \\
\text { people with SCZ }\end{array}$ & $\begin{array}{l}\text { Caregiver burden } \\
\text { Satisfaction }\end{array}$ & $\begin{array}{l}\text { Caregivers burden: } 24.32 \% \\
\text { Satisfaction in caregiving: } \\
57.21 \%\end{array}$ & Weak \\
\hline $\begin{array}{l}\text { Jundong et al } 2012 \\
\text { Sweden }^{51}\end{array}$ & $\begin{array}{l}\text { Birth cohort } \\
\text { (since 1932) }\end{array}$ & $\begin{array}{l}\text { SC54 parents with } \\
\text { SCZ } \\
-1439215 \text { controls }\end{array}$ & $\begin{array}{l}\text { School performance } \\
\text { (9 years) }\end{array}$ & $\begin{array}{l}\text { Influence of parental } \\
\text { schizophrenia on offspring } \\
\text { School performance }(\mathrm{d}=-0.31) \\
\text { After controlling covariates } \\
(\mathrm{d}=-0.18)\end{array}$ & Strong \\
\hline $\begin{array}{l}\text { Mitsonis et al } 2012 \\
\text { Greece }^{40}\end{array}$ & $\begin{array}{l}\text { Comparative } \\
\text { cross- } \\
\text { sectional } \\
9 \text { years }\end{array}$ & $\begin{array}{l}\text { - } 87 \text { caregivers of } \\
\text { people with SCZ } \\
\\
90 \text { controls }\end{array}$ & $\begin{array}{l}\text { Psychological } \\
\text { distress }\end{array}$ & $\begin{array}{l}\text { Higher median symptom score in } \\
\text { caregivers than controls } \\
\text { (global severity index ( } 0.70 \text { vs } 0.34) \text { ) }\end{array}$ & Moderate \\
\hline $\begin{array}{l}\text { Perlick et al } 2016 \\
\text { USA }\end{array}$ & Longitudinal & $\begin{array}{l}500 \text { caregivers' people } \\
\text { with BPD }\end{array}$ & $\begin{array}{l}\text { Caregiver burden } \\
\text { Depression }\end{array}$ & $\begin{array}{l}\text { Baseline, } 6 \text { months and } 12 \text { months } \\
\text { mean CES-D } \\
10.0,9.5 \text { and } 8.7 \\
\text { Caregiver burden score } \\
32.5,27.4 \text { and } 24.4 \text { level of burden } \\
\text { at baseline predicted depression } \\
\text { scores during the follow-up period } \\
\text { ( } p<0.001) \text {. } \\
\text { Level of depression at baseline was } \\
\text { not associated with burden scores } \\
\text { during follow-up }(p=0.20)\end{array}$ & Strong \\
\hline
\end{tabular}


Table 2 Continued

\begin{tabular}{|c|c|c|c|c|c|}
\hline $\begin{array}{l}\text { Author } \\
\text { (year) and country }\end{array}$ & $\begin{array}{l}\text { Study design } \\
\text { and illness } \\
\text { duration }\end{array}$ & $\begin{array}{l}\text { Participants } \\
\text { (number and } \\
\text { relationship) }\end{array}$ & Outcome & Result & $\begin{array}{l}\text { Global quality } \\
\text { rating }\end{array}$ \\
\hline $\begin{array}{l}\text { Ranning et al } 2018 \\
\text { Denmark }\end{array}$ & Longitudinal & $\begin{array}{l}684248 \text { births } \\
\text { between } 1986 \text { and } \\
1996 \\
3806 \text { offspring of } \\
\text { parents with BPD } \\
3895 \text { offspring of } \\
\text { parents with SCZ } \\
\text { Controls }\end{array}$ & $\begin{array}{l}\text { School completion } \\
\text { and performance }\end{array}$ & $\begin{array}{l}\text { No graduation } \\
\text { Schizophrenia in mother (OR } \\
2.32(2.05-2.64) \text { ) } \\
\text { Schizophrenia in father (OR } 2.53 \\
(2.24-2.86) \text { ) } \\
\text { Bipolar in mother (OR } 2.53 \\
(2.24-2.86)) \\
\text { Bipolar in father (OR } 1.16 \\
\text { (0.97-1.38)) } \\
\text { High GPA } \\
\text { Schizophrenia in mother (OR } \\
\text { 0.73 (0.64-0.84)) } \\
\text { Schizophrenia in father (OR } 0.71 \\
\text { (0.63-0.81)) } \\
\text { Bipolar in mother (OR } 1.04 \\
\text { (0.93-1.15)) } \\
\text { Bipolar in father (OR } 1.02 \\
\text { (0.90-1.14)) }\end{array}$ & Strong \\
\hline $\begin{array}{l}\text { Ritsher et al } 2001 \\
\text { USA }^{70}\end{array}$ & $\begin{array}{l}\text { Longitudinal } \\
\text { study } \\
17 \text { years }\end{array}$ & $\begin{array}{l}756 \text { families of people } \\
\text { with MDD matched } \\
\text { with age and sex }\end{array}$ & $\begin{array}{l}\text { Socioeconomic } \\
\text { status } \\
\text { MDD }\end{array}$ & $\begin{array}{l}\text { Parent socioeconomic status } \\
\text { affects child psychological health } \\
\text { Parent or offspring } \\
\text { depression doesn't affect late } \\
\text { socioeconomic status }\end{array}$ & Strong \\
\hline $\begin{array}{l}\text { Roick et al } 2007 \\
\text { Germany and Britain }{ }^{60}\end{array}$ & Cross-sectional & $\begin{array}{l}333 \text { relatives (parents } \\
\text { and others) of people } \\
\text { with } \mathrm{SCZ} \text { in Germany } \\
\text { and } 170 \text { in Britain }\end{array}$ & $\begin{array}{l}\text { Family burden } \\
\text { (IEQ-E) }\end{array}$ & $\begin{array}{l}\text { Family burden was associated } \\
\text { with } \\
\text { Symptoms } \\
\text { Male gender } \\
\text { Unemployment } \\
\text { Marital status } \\
\text { Coping abilities patient contact } \\
\text { British caregivers reported more } \\
\text { burden than German } \\
\text { IEQ=43.2 in Germany and } 46.1 \text { in } \\
\text { Britain }\end{array}$ & Moderate \\
\hline
\end{tabular}

\begin{tabular}{|c|c|c|c|c|c|}
\hline $\begin{array}{l}\text { Romero et al } 2005 \\
\text { USA }^{23}\end{array}$ & $\begin{array}{l}\text { Comparative } \\
\text { cross-sectional }\end{array}$ & $\begin{array}{l}24 \text { families with at } \\
\text { least one parent } \\
\text { with BPD } \\
27 \text { families without } \\
\text { PD }\end{array}$ & $\begin{array}{l}\text { Psychopathology } \\
\text { Family environment }\end{array}$ & $\begin{array}{l}\text { BPD families } \\
\text { Had lower cohesion }(p=0.009) \text { and } \\
\text { expressiveness scores }(p=0.03) \\
\text { Compared with normative data } \\
\text { BPD families reported lower } \\
\text { cohesion and higher conflict }\end{array}$ & Weak \\
\hline $\begin{array}{l}\text { Sanchez et al } 2015 \\
\text { Spain }^{47}\end{array}$ & Longitudinal & 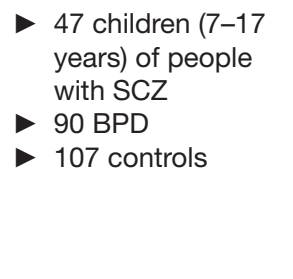 & Psychopathology & $\begin{array}{l}\text { Lifetime axis I DSM-IV psychiatric } \\
\text { disorder } \\
58.5 \% \text { of SCZ offspring } \\
53.7 \% \text { of BP offspring } \\
\quad 17.8 \% \text { of control offspring } \\
\text { Schizophrenia and control } \\
\text { (AOR=3.96) } \\
\text { Bipolar and control (AOR=2.36) }\end{array}$ & Strong \\
\hline $\begin{array}{l}\text { Sucksdorff et al } 2014 \\
\text { Finland }^{38}\end{array}$ & $\begin{array}{l}\text { Nested-case } \\
\text { control }\end{array}$ & $\begin{array}{l}1861 \text { cases with } \\
\text { BPD } \\
3643 \text { matched } \\
\text { controls }\end{array}$ & Psychopathology & $\begin{array}{l}\text { AOR=2.79 for any psychiatric } \\
\text { diagnosis in mothers } \\
\text { AOR=2.5BPD in father and } \\
\text { AOR=BPD } 5.36 \text { in both parents } \\
\text { BPD in offspring is associated with } \\
\text { parental BPD, SCZ and related } \\
\text { psychoses and other affective } \\
\text { disorders }\end{array}$ & Moderate \\
\hline $\begin{array}{l}\text { Van Wijngaarden et al } \\
2004 \\
\text { Netherlands }^{11}\end{array}$ & Cross-sectional & $\begin{array}{l}260 \text { caregivers of } \\
\text { people with MDD }\end{array}$ & $\begin{array}{l}\text { Consequence of } \\
\text { living with a family } \\
\text { member with MDD }\end{array}$ & $\begin{array}{l}\text { Depression }(49.6 \%) \\
\text { Sleeplessness }(53.1 \%) \\
\text { Headache }(44.2 \%) \\
\text { Extreme tiredness }(56.2 \%) \\
\text { 80\% of caregivers reported } \\
\text { distress }\end{array}$ & Moderate \\
\hline
\end{tabular}

Continued 
Table 2 Continued

\begin{tabular}{|c|c|c|c|c|c|}
\hline $\begin{array}{l}\text { Author } \\
\text { (year) and country }\end{array}$ & $\begin{array}{l}\text { Study design } \\
\text { and illness } \\
\text { duration }\end{array}$ & $\begin{array}{l}\text { Participants } \\
\text { (number and } \\
\text { relationship) }\end{array}$ & Outcome & Result & $\begin{array}{l}\text { Global quality } \\
\text { rating }\end{array}$ \\
\hline $\begin{array}{l}\text { Van Wijngaarden et al } \\
2009 \\
\text { Netherlands Denmark } \\
\text { and UK }{ }^{41}\end{array}$ & Cross-sectional & $\begin{array}{l}260 \text { caregivers } \\
\text { of people with } \\
\text { depression } \\
151 \text { caregivers of } \\
\text { SCZ }\end{array}$ & $\begin{array}{l}\text { Burden in SCZ and } \\
\text { depression }\end{array}$ & $\begin{array}{l}\text { Depression versus SCZ } \\
\text { Worried about patient's future } \\
44.8 \% \text { versus } 56.0 \%(p=0.020) \\
\text { Atmosphere was strained } \\
27.4 \% \text { versus } 11.6 \%(p<0.001) \\
\text { Encouraged to take proper care } \\
7.5 \% \text { versus } 24.8 \%(p<0.001)\end{array}$ & Moderate \\
\hline $\begin{array}{l}\text { Weissman et al } 2005 \\
\text { USA }^{25}\end{array}$ & $\begin{array}{l}\text { Longitudinal } \\
20 \text { years and } \\
\text { longer }\end{array}$ & $\begin{array}{l}161 \text { grandchildren } \\
\text { and their parents and } \\
\text { grandparents with and } \\
\text { without depression }\end{array}$ & $\begin{array}{l}\text { Lifetime psychiatric } \\
\text { disorder } \\
\text { Functioning }\end{array}$ & $\begin{array}{l}59.2 \% \text { psychiatric disorder in } \\
\text { grandchildren with } 2 \text { generations of } \\
\text { major depression } \\
\text { Families with a depressed } \\
\text { grandparent } \\
\text { Anxiety (RR, } 5.17(1.4-18.7) \\
\text { Any disorder (RR, } 5.52(2.0-15.4) \\
\text { compared with non-depressed } \\
\text { parents }\end{array}$ & Strong \\
\hline
\end{tabular}

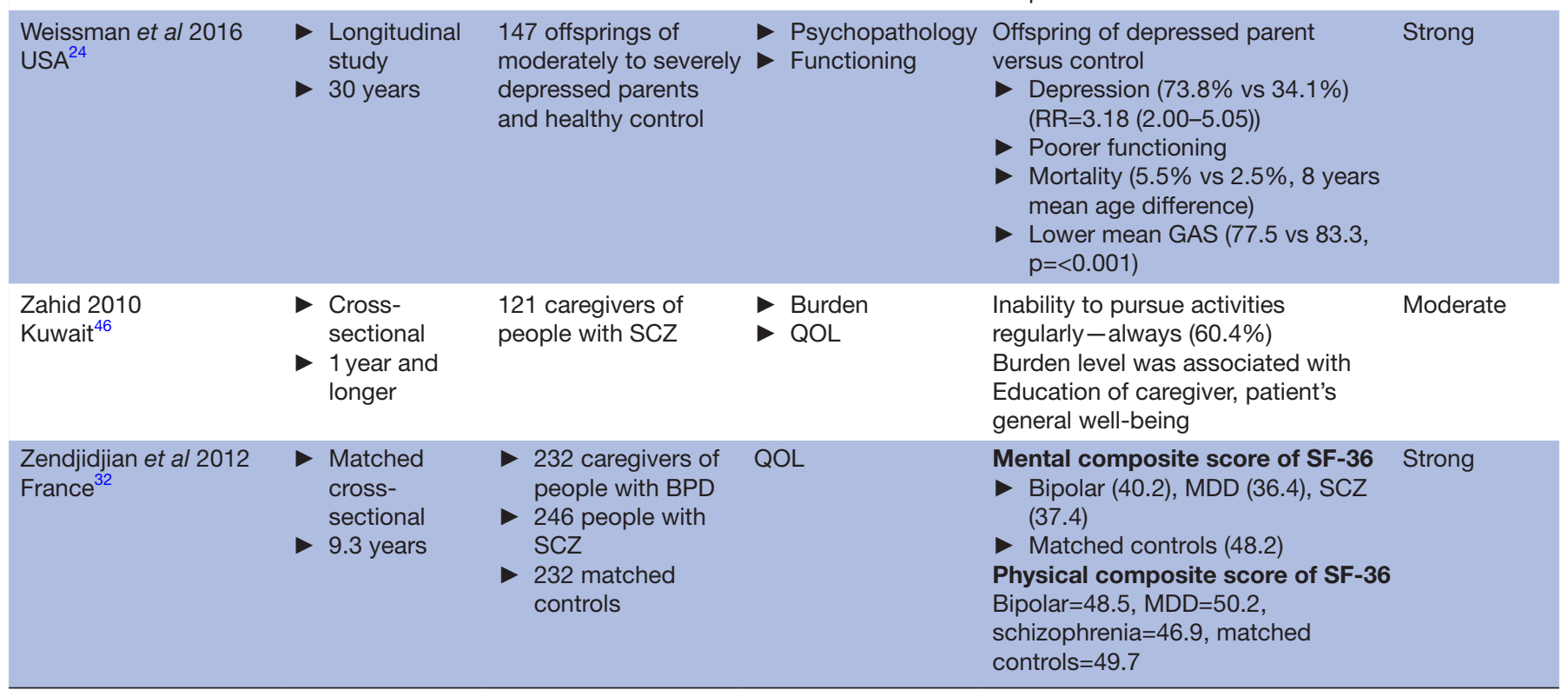

AOR, adjusted OR; BPD, bipolar disorder;CES-D, centre for epidemiological studies of depression scale; CGAS, children's global assessment scale; DSM-IV, diagnostic statistical manual-IV; ES, effect size; GAS, global assessemnt scale; GPA, grade point average; HRQOL, health releated quality of life; IEQ, involvement evaluation questionnaire; IEQ-E, involvement evaluation questionnaire-european version; MCS, mental component score; MDD, major depressive disorder;NA, negative affect; QOL, quality of life;RR, relative risk; SCZ, schizophrenia; SF-12, short form-12; SF-36, short form-36; SMD, severe mental disorder;SMI, severe mental illness; SOC, sense of coherence; SSP, schizophrenia spectrum psychosis.

Studies with comparison group help us to ascertain the contribution of the illness for such high level of psychopathology among family members. ${ }^{24} 33404868$ Higher risk for psychological problems can also be attributed to genetic predispositions. $^{69}$

The social-economic impacts include temporary and short-term social and economic problems such as divorce, family cohesion problems and economic costs related to treatment and disability. It may also result in long-term socioeconomic drift, low marriage, less employment and greater food insecurity. This supports the previously established social causation (mental illness causes socioeconomic drift) and social selection (mental illness is common in people with low socioeconomic status) models in both low/high-income countries. ${ }^{70}$ However, most of the impacts vary with setting and previous socioeconomic status. So, any intervention should be done based on local longitudinal evidence. ${ }^{42-44}$

Studies that explore the impacts of parental SMI on children largely focus on psychopathology and show this to be higher in children of parents with SMI than in other children. These problems are attributed both to preventable and unpreventable factors. The preventable factors include poor childcare including failing to fulfil basic needs as well as physical and emotional abuse on children by parents with the illness. Though it is reported by a single article, mortality was also higher in these children. ${ }^{24}$ Further studies will be needed to ascertain this mortality report especially in low-income countries where there is high treatment gap for mental illness and 
high child mortality rate. ${ }^{72} 73$ Problems with children's schooling and growth were reported in high-income countries while nutritional problems were reported in low-income setting. ${ }^{49-53}$ But as there is a lack of social security system in most LMICs, more studies and intervention programme are needed in children's schooling and nutrition.

The current family inclusive interventions mostly focused on solving psychological distresses in family members. ${ }^{74-77}$ But our review shows that the impact is multidimensional which may need designing of multidimensional interventions: economic, school, social and psychological.

\section{STRENGTHS AND LIMITATIONS}

The comprehensive nature of this review based on four databases and grey literature with detailed search strategies is the major strength. Limitations include the fact that most of the included reports were from high-income countries, which make it difficult to generalise for the global setting. About one in five studies was also rated methodologically weak.

\section{CONCLUSIONS}

The review shows that SMI had multidimensional, longterm and generational impacts on family members. The impact was distributed in grandparents, parents, siblings, offspring and spouses. This was true in schizophrenia, bipolar disorder and major depression. The review indicated a need for longitudinal research in community settings, and different population groups (eg, urban and rural), especially in low-income countries.

\section{Twitter Abebaw Fekadu @abebawfekadu}

Contributors WF and AF conceived the study and they were part of the whole process of the review. AM participated in screening and quality assessment. TKJC reviewed all versions and made corrections. All the authors read and approved the final version.

Funding This work was supported through the DELTAS Africa Initiative (DEL-1501). The DELTAS Africa Initiative is an independent funding scheme of the African Academy of Sciences (AAS) Alliance for Accelerating Excellence in Science in Africa and supported by the New Partnership for Africa's Development Planning and Coordinating Agency (NEPAD Agency) with funding from the Wellcome Trust (DEL15-01) and the UK government. The views expressed in this publication are those of the author(s) and not necessarily those of AAS, NEPAD Agency, WellcomeTrust or the UK government.

Competing interests None declared.

Patient consent for publication Not required.

Provenance and peer review Not commissioned; externally peer reviewed.

Data availability statement Data sharing not applicable as no data sets generated and/or analysed for this study. All data relevant to the study are included in the article or uploaded as supplementary information.

Open access This is an open access article distributed in accordance with the Creative Commons Attribution Non Commercial (CC BY-NC 4.0) license, which permits others to distribute, remix, adapt, build upon this work non-commercially, and license their derivative works on different terms, provided the original work is properly cited, appropriate credit is given, any changes made indicated, and the use is non-commercial. See: http://creativecommons.org/licenses/by-nc/4.0/.
ORCID iD

Wubalem Fekadu http://orcid.org/0000-0001-7418-4955

\section{REFERENCES}

1 Drake RE, Essock SM, Shaner A, et al. Implementing dual diagnosis services for clients with severe mental illness. Psychiatr Serv 2001;52:469-76.

2 Mojtabai R, Stuart EA, Hwang I, et al. Long-Term effects of mental disorders on educational attainment in the National comorbidity survey ten-year follow-up. Soc Psychiatry Psychiatr Epidemiol 2015;50:1577-91.

3 Jenkins R, Baingana F, Ahmad R, et al. Mental health and the global agenda: core conceptual issues. Mental health in family medicine 2011;8:69.

4 Fekadu A, Medhin G, Kebede D, et al. Excess mortality in severe mental illness: 10-year population-based cohort study in rural Ethiopia. British Journal of Psychiatry 2015;206:289-96.

5 Teferra S, Shibre T, Fekadu A, et al. Five-Year mortality in a cohort of people with schizophrenia in Ethiopia. BMC Psychiatry 2011;11:1.

6 Liu NH, Daumit GL, Dua T, et al. Excess mortality in persons with severe mental disorders: a multilevel intervention framework and priorities for clinical practice, policy and research agendas. World Psychiatry 2017;16:30-40.

7 Thornicroft G, Tansella M, Becker T, et al. The personal impact of schizophrenia in Europe. Schizophr Res 2004;69:125-32.

8 Panayiotopoulos C, Pavlakis A, Apostolou M. Family burden of schizophrenic patients and the welfare system; the case of Cyprus. Int J Ment Health Syst 2013;7:13.

9 Ae-Ngibise KA, Doku VCK, Asante KP, et al. The experience of caregivers of people living with serious mental disorders: a study from rural Ghana. Glob Health Action 2015;8:26957.

10 Hoenig J, Hamilton MW. The schizophrenic patient in the community and his effect on the household. Int J Soc Psychiatry 1966;12:165-76.

11 van Wijngaarden $\mathrm{B}$, Schene $\mathrm{AH}$, Koeter MWJ. Family caregiving in depression: impact on caregivers' daily life, distress, and help seeking. J Affect Disord 2004;81:211-22.

12 Gallagher SK, Mechanic D. Living with the mentally ill: effects on the health and functioning of other household members. Soc Sci Med 1996;42:1691-701.

13 Pompili Met al. Impact of living with bipolar patients: Making sense of caregivers' burden. World J Psychiatry 2014;4:1-12.

14 Mattejat F, Remschmidt $\mathrm{H}$. The children of mentally ill parents. Dtsch Arztebl Int 2008;105:413-8.

15 Hosman CMH, van Doesum KTM, van Santvoort F. Prevention of emotional problems and psychiatric risks in children of parents with a mental illness in the Netherlands: I. The scientific basis to a comprehensive approach. AeJAMH 2009;8:250-63.

16 Goodman SH, Gotlib IH. Risk for psychopathology in the children of depressed mothers: a developmental model for understanding mechanisms of transmission. Psychol Rev 1999;106:458-90.

17 Gotlib IH, Goodman SH. Children of parents with depression. psycnet.apa 1999.

18 Homlong L, Rosvold EO, Sagatun Åse, et al. Living with mentally ill parents during adolescence: a risk factor for future welfare dependence? A longitudinal, population-based study. BMC Public Health 2015;15:1.

19 Crowe A, Brinkley J. Distress in caregivers of a family member with serious mental illness. The Family Journal 2015;23:286-94.

20 Roick C, Heider D, Toumi M, et al. The impact of caregivers characteristics, patients' conditions and regional differences on family burden in schizophrenia: a longitudinal analysis. Acta Psychiatr Scand 2006;114:363-74.

21 Schene $A H$, van Wijngaarden B, Koeter MWJ. Family caregiving in schizophrenia: domains and distress. Schizophr Bull 1998;24:609-18.

22 Tirfessa K, Lund C, Medhin G, et al. Food insecurity among people with severe mental disorder in a rural Ethiopian setting: a comparative, population-based study. Epidemiology and psychiatric sciences 2017:1-11.

23 Romero S, DelBello MP, Soutullo CA, et al. Family environment in families with versus families without parental bipolar disorder: a preliminary comparison study. Bipolar Disord 2005;7:617-22.

24 Weissman MM, Wickramaratne P, Gameroff MJ, et al. Offspring of depressed parents: 30 years later. Am J Psychiatry 2016;173:1024-32.

25 Weissman MM, Wickramaratne P, Nomura Y, et al. Families at high and low risk for depression: a 3-generation study. Archives of general psychiatry 2005;62:29-36. 
26 Steele A, Maruyama N, Galynker I. Psychiatric symptoms in caregivers of patients with bipolar disorder: a review. J Affect Disord 2010;121:10-21.

27 Beentjes TAA, Goossens PJJ, Poslawsky IE. Caregiver burden in bipolar hypomania and mania: a systematic review. Perspect Psychiatr Care 2012;48:187-97.

28 Millier A, Schmidt U, Angermeyer MC, et al. Humanistic burden in schizophrenia: a literature review. J Psychiatr Res 2014;54:85-93.

29 Moher D, Liberati A, Tetzlaff J, et al. Preferred reporting items for systematic reviews and meta-analyses: the PRISMA statement. PLoS Med 2009;6:e1000097.

30 Higgins JP, Green S. Cochrane Handbook for systematic reviews of interventions. John Wiley \& Sons, 2011.

31 Armstrong R, Waters E, Jackson N. Systematic reviews of health promotion and public health interventions. Melbourne: University of Melbourne, 2007.

32 Zendjidjian X, Richieri R, Adida M, et al. Quality of life among caregivers of individuals with affective disorders. J Affect Disord 2012;136:660-5.

33 Aschbrenner KA, Greenberg JS, Seltzer MM. Parenting an adult child with bipolar disorder in later life. J Nerv Ment Dis 2009;197:298-304.

34 Thunyadee C, Sitthimongkol Y, Sangon S, et al. Predictors of depressive symptoms and physical health in caregivers of individuals with schizophrenia. Nurs Health Sci 2015;17:412-9.

35 Gupta S, Isherwood G, Jones K, et al. Assessing health status in informal schizophrenia caregivers compared with health status in non-caregivers and caregivers of other conditions. BMC Psychiatry 2015;15:162.

36 Parabiaghi A, Lasalvia A, Bonetto $\mathrm{C}$, et al. Predictors of changes in caregiving burden in people with schizophrenia: a 3-year follow-up study in a community mental health service. Acta Psychiatr Scand 2007;116:66-76.

37 Perlick DA, Berk L, Kaczynski R, et al. Caregiver burden as a predictor of depression among family and friends who provide care for persons with bipolar disorder. Bipolar Disord 2016;18:183-91.

38 Sucksdorff D, Chudal R, Suominen A, et al. Bipolar disorder and parental psychopathology. Soc Psychiatry Psychiatr Epidemiol 2014;49:1973-84.

39 Terzian ACC, Andreoli SB, de Oliveira LM, et al. A cross-sectional study to investigate current social adjustment of offspring of patients with schizophrenia. Eur Arch Psychiatry Clin Neurosci 2007;257:230-6.

40 Mitsonis C, Voussoura E, Dimopoulos N, et al. Factors associated with caregiver psychological distress in chronic schizophrenia. Soc Psychiatry Psychiatr Epidemiol 2012;47:331-7.

41 van Wijngaarden B, Koeter M, Knapp M, et al. Caring for people with depression or with schizophrenia: are the consequences different? Psychiatry Res 2009;169:62-9.

42 Igberase OO, Morakinyo O, Lawani AO, et al. Burden of care among relatives of patients with schizophrenia in midwestern Nigeria. Int $J$ Soc Psychiatry 2012;58:131-7.

43 Shibre T, Kebede D, Alem A, et al. Schizophrenia: illness impact on family members in a traditional society - rural Ethiopia. Soc Psychiatry Psychiatr Epidemiol 2003;38:27-34.

44 Shibre T, Medhin G, Teferra S, et al. Predictors of carer-burden in schizophrenia: a five-year follow-up study in Butajira, Ethiopia. Ethiop Med J 2012;50:125-33.

45 Zergew A, Hailemariam D, Alem A, et al. A longitudinal comparative analysis of economic and family caregiver burden due to bipolar disorder. Afr J Psychiatry 2008;11:191-8.

46 Zahid MA, Ohaeri JU. Relationship of family caregiver burden with quality of care and psychopathology in a sample of Arab subjects with schizophrenia. BMC Psychiatry 2010;10:71.

47 Sanchez-Gistau V, Romero S, Moreno D, et al. Psychiatric disorders in child and adolescent offspring of patients with schizophrenia and bipolar disorder: a controlled study. Schizophr Res 2015;168:197-203.

48 Ellersgaard D, Jessica Plessen K, Richardt Jepsen J, et al. Psychopathology in 7-year-old children with familial high risk of developing schizophrenia spectrum psychosis or bipolar disorder - The Danish High Risk and Resilience Study - VIA 7, a populationbased cohort study. World Psychiatry 2018;17:210-9.

49 Henin A, Biederman J, Mick E, et al. Psychopathology in the offspring of parents with bipolar disorder: a controlled study. Biol Psychiatry 2005;58:554-61.

50 Schubert EW, McNeil TF. Prospective study of adult mental disturbance in offspring of women with psychosis. Arch Gen Psychiatry 2003;60:473-80.

51 Jundong J, Kuja-Halkola R, Hultman C, et al. Poor school performance in offspring of patients with schizophrenia: what are the mechanisms? Psychol Med 2012;42:111-23.
52 Ashaba S, Rukundo GZ, Beinempaka F, et al. Maternal depression and malnutrition in children in Southwest Uganda: a case control study. BMC Public Health 2015;15:1303.

53 Ranning A, Laursen T, Agerbo E, et al. School performance from primary education in the adolescent offspring of parents with schizophrenia and bipolar disorder- a national, register-based study. Psychol Med 2018;48:1993-2000.

54 Gutiérrez-Maldonado J, Caqueo-Urízar A, Kavanagh DJ. Burden of care and general health in families of patients with schizophrenia. Soc Psychiatry Psychiatr Epidemiol 2005;40:899-904.

55 Chessick CA, Perlick DA, Miklowitz DJ, et al. Suicidal ideation and depressive symptoms among bipolar patients as predictors of the health and well-being of caregivers. Bipolar Disord 2009;11:876-84.

56 Donatelli J-AL, Seidman LJ, Goldstein JM, et al. Children of parents with affective and nonaffective psychoses: a longitudinal study of behavior problems. Am J Psychiatry 2010;167:1331-8.

57 Hanzawa S, Tanaka G, Inadomi H, et al. Burden and coping strategies in mothers of patients with schizophrenia in Japan. Psychiatry Clin Neurosci 2008;62:256-63.

58 Hsiao C-Y, Tsai Y-F. Factors of caregiver burden and family functioning among Taiwanese family caregivers living with schizophrenia. J Clin Nurs 2015;24:1546-56.

$59 \mathrm{CW}$ Lam P, Ng P, Tori C. Burdens and psychological health of family caregivers of people with schizophrenia in two Chinese metropolitan cities: Hong Kong and Guangzhou. Community Ment Health J 2013:49:841-6.

60 Roick C, Heider D, Bebbington PE, et al. Burden on caregivers of people with schizophrenia: comparison between Germany and Britain. Br J Psychiatry 2007;190:333-8.

61 Girma E, Tesfaye M, Froeschl G, et al. Public stigma against people with mental illness in the Gilgel Gibe field research center (GGFRC) in Southwest Ethiopia. PLoS One 2013;8:e82116.

62 Girma E, Möller-Leimkühler AM, Dehning S, et al. Self-stigma among caregivers of people with mental illness: toward caregivers' empowerment. J Multidiscip Healthc 2014;7:37.

63 Saxena S, Thornicroft G, Knapp M, et al. Resources for mental health: scarcity, inequity, and inefficiency. The Lancet 2007;370:878-89.

64 De Andres-Garcia S, Cano-Lopez I, Moya-Albiol L, et al. Negative affect, perceived health, and endocrine and immunological levels in caregivers of offspring with schizophrenia. Psicothema 2016;28:377-82.

65 Rice PL. Stress and health: Brooks/Cole publishing Pacific Grove. CA 1999.

66 Thoits PA. Stress and health: major findings and policy implications. $J$ Health Soc Behav 2010;51:S41-53.

67 Vitaliano PP, Zhang J, Scanlan JM. Is caregiving hazardous to one's physical health? A meta-analysis. Psychol Bull 2003;129:946-72.

68 Petresco S, Gutt EK, Krelling R, et al. The prevalence of psychopathology in offspring of bipolar women from a Brazilian tertiary center. Revista Brasileira de Psiquiatria 2009;31:240-6.

69 Kinney DK, Matthysse S. Genetic transmission of schizophrenia. Annu Rev Med 1978;29:459-73.

70 Ritsher JEB, Warner V, Johnson JG, et al. Inter-Generational longitudinal study of social class and depression: a test of social causation and social selection models. British J Psychiat 2001;178:s84-90.

71 Johnson JG, Cohen P, Dohrenwend BP, et al. A longitudinal investigation of social causation and social selection processes involved in the association between socioeconomic status and psychiatric disorders. J Abnorm Psychol 1999;108:490-9.

72 Demyttenaere K, Bruffaerts R, Posada-Villa J, et al. Prevalence, severity, and unmet need for treatment of mental disorders in the world Health organization world mental health surveys. Jama 2004;291:2581-90.

73 Viner RM, Coffey C, Mathers C, et al. 50-Year mortality trends in children and young people: a study of 50 low-income, middleincome, and high-income countries. The Lancet 2011;377:1162-74.

74 Baruch E, Pistrang N, Barker C. Psychological interventions for caregivers of people with bipolar disorder: a systematic review and meta-analysis. J Affect Disord 2018;236:187-98.

75 Reinares M, Bonnín CM, Hidalgo-Mazzei D, et al. The role of family interventions in bipolar disorder: a systematic review. Clin Psychol Rev 2016;43:47-57.

76 Okpokoro U, Adams CE, Sampson S. Family intervention (brief) for schizophrenia. Cochrane Database Syst Rev 2014;3:Cd009802.

77 Bee P, Bower P, Byford S, et al. The clinical effectiveness, costeffectiveness and acceptability of community-based interventions aimed at improving or maintaining quality of life in children of parents with serious mental illness: a systematic review. Health Technol Assess 2014;18:1-250. 